\title{
A Science Teacher's Companion to the BBC Microcomputer
}




\section{Macmillan Microcomputer Books}

General Editor: Ian Birnbaum (Adviser for Microelectronics in Education, Humberside LEA)

Advanced Graphics with the Acorn Electron

Ian O. Angell and Brian J. Jones

Advanced Graphics with the BBC Microcomputer

Ian O. Angell and Brian J. Jones

Assembly Language Programming for the Acorn Electron

Ian Birnbaum

Assembly Language Programming for the BBC Microcomputer, second edition

Ian Birnbaum

Using Your Home Computer

Garth W.P.Davies

A Science Teacher's Companion to the BBC Microcomputer

Philip Hawthorne

Beginning BASIC with the ZX Spectrum

Judith Miller

Using Sound and Speech on the BBC Microcomputer

M. A. Phillips

\section{Also from Macmillan}

Advanced Graphics with the Sinclair ZX Spectrum

Ian O. Angell and Brian J. Jones

Advanced Programming for the 16K ZX81 Mike Costello

Beginning BASIC Peter Gosling

Continuing BASIC Peter Gosling

Practical BASIC Programming Peter Gosling

Program Your Microcomputer in BASIC Peter Gosling

Codes for Computers and Microprocessors P. Gosling and Q. Laarhoven

Microprocessors and Microcomputers - their use and programming

Eric Huggins

The Sinclair ZX81 - Programming for Real Applications

Randle Hurley

More Real Applications for the ZX81 and ZX Spectrum Randle Hurley

Programming in Z80 Assembly Language Roger Hutty

Digital Techniques Noel Morris

Microprocessor and Microcomputer Technology Noel Morris

The Alien, Numbereater, and Other Programs for Personal Computers with notes on how they were written John Race

Understanding Microprocessors B. S. Walker

Assembly Language Assembled - for the Sinclair ZX81

Anthony Woods 


\title{
A Science Teacher's Companion to the BBC Microcomputer
}

\author{
Philip Hawthorne \\ Portadown College \\ Co. Armagh
}

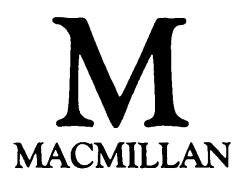


(c) Philip Hawthorne 1985

All rights reserved. No reproduction, copy or transmission of this publication may be made without written permission.

No paragraph of this publication may be reproduced, copied or transmitted save with written permission or in accordance with the provisions of the Copyright Act 1956 (as amended).

Any person who does any unauthorised act in relation to this publication may be liable to criminal prosecution and civil claims for damages.

First published 1985

Published by

Higher and Further Education Division

MACMILLAN PUBLISHERS LTD

Houndmills, Basingstoke, Hampshire RG21 2XS

and London

Companies and representatives

throughout the world

British Library Cataloguing in Publication Data

Hawthorne, Philip

A science teacher's companion to the BBC

Microcomputer. - (Macmillan microcomputer books)

1. Science-Computer-assisted instruction

I. Title

$507^{\prime} .8$

Q183.9

ISBN 978-0-333-38285-1

ISBN 978-1-349-07644-4 (eBook)

DOI 10.1007/978-1-349-07644-4

Associated software cassette: 978-0-333-39094-8 


\section{Contents}

PREFACE

vii

1 THE SCIENCE MACHINE

An introduction to the use of the $B B C$ microcomputer in Science education, the BBC micro as a teaching aid, as a scientific instrument and as an administrative aid for testing, stock control, word processing etc.

\section{SIMULATIONS, DEMONSTRATIONS AND TUTORIALS}

Program listings covering several areas of Science at various levels, and using various programming techniques, with detailed notes to explain how each program works. See software list for program details.

\section{CONTROL AND MEASUREMENT - INTERFACING}

The user port: User port addresses, connections, buffer circuit, breadboard circuits, using port B, logical masking, connecting switch to user port, User port program examples, relay driving circuit. Using the timers in the via: Interrupts, vectors, Timer operating modes, handling interrupts, counting pulses, real-time clock, millisecond timer.

Events: Various events described, audio feedback from keyboard, automatic data acquisition.

Analogue port: Analogue to digital conversion, resolution, ADVAL, *FX16, experiments with the analogue port, connection details, voltage divider circuit, light sensor, details of other sensors, temperature measurement, capacitor discharge, analogue display program. 
Digital to analogue converter: setting up and testing the DAC, generating low frequency sawtooth and sine waves, a programmable audio oscillator, voltmeter teaching aid, plotting diode and transistor characteristics.

A simple robot: Construction, circuit details, testing, controlling the robot, controller programs.

\section{TESTING, FILES AND RECORD KEEPING}

Computer based tests, inputs and data, quiz program, multiple choice programs, files, class record program, file operations, notes on disk files, disk file format, modifying listed programs to work on disks, random access files, pupil record program, index sequential files, simple stock control program.

\section{USING ASSEMBLY LANGUAGE}

The advantages of assembler, differences between machine code and assembler, some assembly language instructions described, indexed addressing, large character program, machine code timing, fast moving graphics, kinetic model of a gas.

Appendix A: Bibliography

Appendix B : Suppliers'Addresses

Appendix C: Components for Chapter 3

Software List 


\section{Preface}

The prefaces of books are probably more cliche-ridden than any other part of the text but I really do owe a deep debt of gratitude to the numerous people who assisted in various ways during the writing of this book. I mention them in no particular order and if I omit anyone I hope he or she will forgive me.

Many of my pupils gladly acted as 'guinea pigs' when the programs were being tested and many offered helpful suggestions for improvements. In particular I would like to thank Ian McAlpine for lending his extensive knowledge and, on occasions his computer. Mrs Dorothy McCaughey provided many helpful suggestions and cheerfully waded her way through the early drafts with her red pen! Mr Gerry Lappin of the local School's Computer Centre kindly loaned equipment and offered encouragement.

To all my colleagues in Portadown college who took an interest in the project and especially to $\mathrm{Mr} \mathrm{T} . \mathrm{H}$. Armstrong and $\mathrm{Mr}$ Bertie Fulton for allowing me to utilise the school equipment and facilities, a really big thank you.

And last, but by no means least, many thanks to Carol, to whom this book is dedicated, for helping with the typing, proof reading, supplying countless sandwiches and cups of tea and for being so patient and understanding.

The program listings have been displayed such that long lines have been indented where they have been broken to fit onto the page; on these occasions, please exercise a degree of caution when keying in, to ensure that the integrity of each line is maintained.

Throughout the text I have used the masculine pronoun only, to aid readability; it goes without saying that this encompasses both male and female readers! 